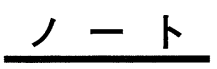

\title{
スクロース =モノパルミタート希薄水溶液の表面物性
}

\author{
高木 和行* ・平井 誠道* ・藤沼 幸雄 ${ }^{*}$ 藤松 仁 ${ }^{*}$ \\ 宇佐美久尚* - 小笠原真次 ${ }^{*} \cdot$ 笠原 由子 ${ }^{* *}$ ・結城 明文** \\ * 信州大学䄉維学部（开 386 上田市常田3-15-1) \\ ** 三菱化成（株）総合研究所（广 227 横浜市青葉区鴨志田町 1000 )
}

Surface Properties in Aqueous Dilute Solutions of Sucrose Monopalmitate

Kazuyuki Takagi, Masamichi Hirai, Yukio Fujinuma, Hitoshi Fujimatsu,

Hisanao Usami, Shinji Ogasawara, Yoshiko Kasahara, and Akifumi Yuki

* Faculty of Textile Science and Technology, Shinshu University (3-15-1 Tokida, Ueda-shi, ₹ 386)

** Research Center, Mitsubishi Kasei Corp. (1000, Kamoshida-cho, Aoba-ku, Yokohama-shi, $\mathbf{T} 227$ )

The surface tension of aqueous dilute solutions of sucrose monopalmitate was measured as a function of surfactant concentration at various temperatures under atmospheric pressure. Specific behavior was observed that not indicate the surface activity by a certain concentration below cmc.

Such specific behavior was also demonstrated by change in surface tension with time. At the concentrations lower than cmc, the surface tension was initially relatively low, gladually increased, and finally became essentially the same as that of pure water with time.

At the concentrations higher than $\mathrm{cmc}$, the surface tension decreased with time and finally become a constant value. The existence of the concentration region which is not indicate surface activity is assumed that the sucrose fatty ester is not absorpt the vapor-liquid surface because of dominant incorporation of the sucrose into water structure.

\section{1 緒 言}

スクロース脂肪酸エステルは, 食品添加物として認可 されている数少ない界面活性剂の一つであり, 現在では 食品工業における乳化剤として久くことのできない界面 活性剂となっている。また, スクロース脂肪酸エステル は，スクロース中のヒドロキシル基と脂肪酸とのエステ ル化の度合いにより, 親水性から親油性までの幅広い HLB を持つものを合成することが可能であることか ら，その利用範囲も極めて広いという特徽を有してい る。

これまでのスクロース脂肪酸エステルについての研究 は大部分が，モノ，ジ，およびトリエステルなどの混合

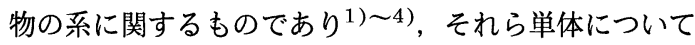
の研究は比較的少ない。特に, 高純度のスクロース脂肪 酸エステルについての報告例は, $\mathrm{cmc}$ 近傍に限られて

連絡者 : 高木和行
いる5)。一般に界面活性剂の物性は第三物質を微量添加 することにより，著しく変化することが知られている。

そこで本研究では, 高純度のスクロース脂肪酸エステ ルについて, $\mathrm{cmc}$ 付近及び, それ以下の低濃度域に注 目し, 希薄溶液の表面張力法により種々検討した。

\section{2 実験}

$2 \cdot 1$ スクロース脂肪酸エステル

実験に使用したスクロース脂肪酸エステルは, 脂肪酸 としてパルミチン酸を用いたスクロース＝モノパルミ タートである。Fig.-1に示すように，スクロースの第 一級ヒドロキシル基がパルミチン酸により優先的にエス テル化される。図中の $\mathrm{A}$ は $\mathrm{COR}\left(\mathrm{R}: \mathrm{C}_{15} \mathrm{H}_{31}\right)$ であ る。本試料は，特にこれらヒドロキシル基のうちグル コース側の第一級ヒドロキシル基である第 6 位のヒドロ キシル基が優先してエステル化されたものである。 本実験に用いた試料は, 三菱化成（株）総合研究所に 


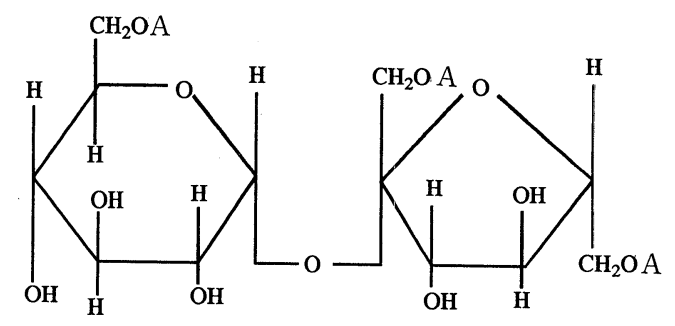

Fig.-1 Sucrose esters of palmitic acid.

より，合成並びに精製されたものである。その精製方法 は, 次のとおりである。

モノエステル約 $77 \%$, ジエステル約 $18 \%$ 及び, 卜 リエステル約 $4 \%$ を含むスクロース=パルミタートの 混合物をクロロホルムに溶解し, 直径 $2.5 \mathrm{~cm}$, 長さ 20 $\mathrm{cm}$ のシリカゲルカラムで分別した。展開溶媒として, クロロホルム : メタノール : 水の割合が体積比で, 80 : $20: 3$ の混合溶媒を用い, 各流出分画中のスクロース脂 肪酸エステルを示差屈折計で検出した。得られたモノエ ステルの分画中の溶媒はロータリーエバポレーターによ り除去し, 乾燥した。得られた試料の純度は, 液体ク口 マトグラフィーにより $99.8 \%$ 以上であることが確認さ れた。

\section{$2 \cdot 2$ 試料溶液の調製}

所定量の試料を 2 回蒸留水に溶解し, 常温で一昼夜放 置したものを测定試料とした。

\section{$2 \cdot 3$ 実験方法}

溶液の表面張力測定には, 協和科学株式会社製のウィ ルヘルミー式表面張力計 $A-1$ 型及び株式会社レスカ製 動的ぬ(需)れ性試験器 WET-6000 型を使用した。2つ の機種により測定した結果を比較して, 表面張力の值 が, 装置に依存しないことを確認した。前者は, 単純に ガラス製の平板状プレートを引き下げようと作用してい る表面張力をねじりはかりで測定する方式のもので, 後 者は, 表面張力により引き下げられたガラス製の平板状 プレートを平衡位置にまで引きもどすのに要する力を差 動トランスの電力により検出する方式のものである。特 に後者は, プレートの一部が液中にあるので, 表面吸着 平衡に達するのに要する時間が長い場合は, 水分の蒸発 の影響が比較的少ないと考えられる。

これらの装置を用いて, 種々の濃度溶液の表面張力を $293.1 \mathrm{~K}, 303.1 \mathrm{~K}, 318.1 \mathrm{~K}, 323.1 \mathrm{~K}$ 及び, $333.1 \mathrm{~K}$ で 測定した。溶液温度は, 溶液を満たした容器のジャケッ 卜に恒温水を循環することにより, $\pm 0.1^{\circ} \mathrm{C}$ 精度で制 御した。また, 水の蒸発の影響を僅少にするため, ジャ ケットと容器の間に測定溶液と同一の溶液を満たしてか ら覆いをして, ガラスプレートの周りに平衡蒸気が充満 するようにした。

\section{3 結 果}

\section{$3 \cdot 1$ 平衡表面張力の濃度依存性及び温度の影響}

表面張力の経時変化を考慮し, 一定値となったときの 值を平衡表面張力として採用した。

$303.1 \mathrm{~K}$ で測定した平衡表面張力を濃度の対数に対して プロットした結果をFig.-2に示す。図を見ると，希薄 濃度域の表面張力が, 界面活性剂濃度によらず, 一定で 水の表面張力と同一に保たれる領域のあることがわか る。この場合, $8.1 \times 10^{-6} \mathrm{M}$ を越えると初めて表面張力 が低下し始め, その後 $\mathrm{cmc}$ に相当する濃度に達すると 一定值をとるようになることがわかる。

アニオン界面活性剂である硫酸アルキルニナトリウム や非イオン界面活性剂であるアルキル＝ポリ（オキシエ チレン) =エーテルなどの水溶液では, 溶液濃度の増加 に伴って次第に表面張力が減少し, $\mathrm{cmc}$ に達すると一 定値をとることが知られている。

平衡表面張力を濃度に対してプロットした結果, Fig. -3 が得られた。

Fig.-2 で観察された現象は，温度 293.1 K, 313.1 K, 318.1 K, $323.1 \mathrm{~K}$ 及び $333.1 \mathrm{~K}$ で測定したいずれの 結果においても確認された。従って, Fig.-2で観測さ れた表面張力が低下しない現象は，本スクロース脂肪酸 エステルに特異な現象であると思われる。

既に馬場ら ${ }^{1)}$ は, 同様な界面活性剤について表面張力 を測定しているが, 本研究のような低濃度領域での測定 は行っていないため, このような現象に関して何ら言及 していない。

また，表面張力が低下しはじめる点は，本実験の範囲 内では温度が変化してもほとんど変わらなかった。従っ て, 本スクロース脂肪酸エステルの表面張力の濃度依存

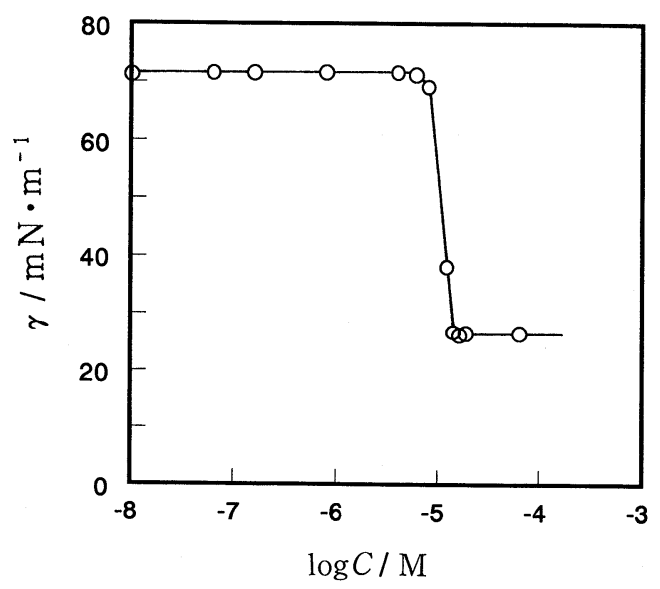

Fig.-2 The relationship between the surface tension and $\log C$ of sucrose palmitate at $303.1 \mathrm{~K}$. 


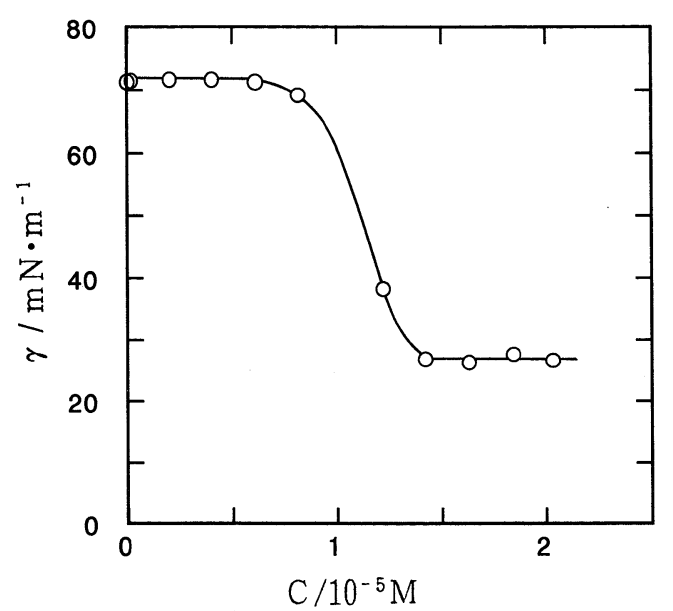

Fig. -3 The relationship between the surface tension and the concentration of sucrose palmitate at $303.1 \mathrm{~K}$.

Table-1 cmc values of sucrose palmitate. cmc $\left(10^{-5} \mathrm{M}\right)$

Temp. (K) Exp. T. Baba ${ }^{1)}$ W. Wachs ${ }^{4)}$ D.Abran ${ }^{5)}$

\begin{tabular}{ccccc}
293.1 & 1.00 & - & 1.10 & - \\
295.1 & - & - & - & 6.00 \\
298.1 & - & 9.50 & - & - \\
303.1 & 1.38 & - & - & - \\
313.1 & 1.78 & - & - & - \\
318.1 & 1.86 & - & - & - \\
323.1 & 2.14 & - & - & - \\
333.1 & 2.51 & - & - & - \\
\hline
\end{tabular}

性の結果は, バルク濃度が増加しても, 特定の濃度まで は, 界面活性剤分子が界面に吸着しないことを示唆して いるものと考えられる。

次に, $\mathrm{cmc}$ の值を求め比較検討した。

本実験において表面張力の濃度依存性より得られた cmc の值を Table-1 に示す。これらの值は，スクロー ス=モノパルミタートについて, du Nouy の円環法を 用いた表面張力法により得られた, 馬場1), $\mathrm{Wachs}^{4)}$, Abran ら5)の值より低い。

これは, 後述するように本界面活性剤の場合吸着平衡 に長時間を要するにもかかわらず, 馬場ら五の場合は測 定開始より $5 \mathrm{~min}$ 後, Wachs $ら^{4)}$ の場合は $200 \mathrm{~min}$ 後 の表面張力の值を採用しているため, それらの間に差が 生じたものと考えられる。

cmc の温度依存性を Fig. -4 に示した。

非イオン界面活性剂である本界面活性剂はポリオシキ エチレン型のものとは異なり, 温度上昇に対しては溶解 性增大傾向を有することがわかる。

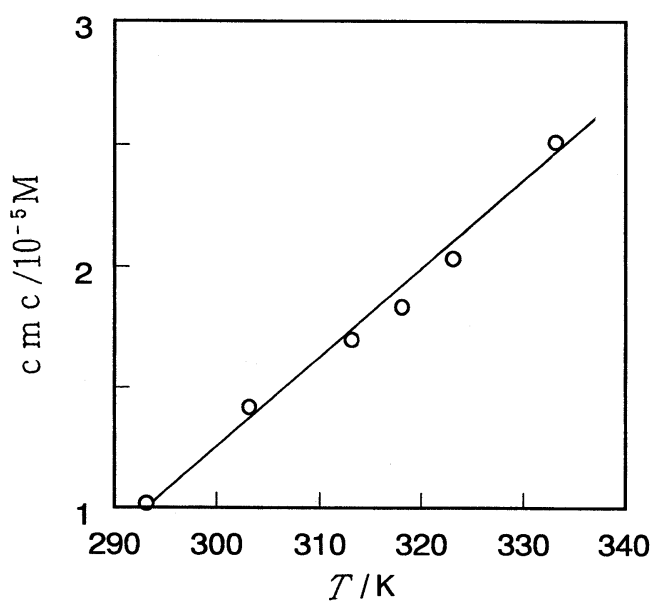

Fig. -4 The relationship between the $\mathrm{cmc}$ of sucrose palmitate and temperature.

\section{$3 \cdot 2$ 表面張力の経時变化}

表面張力の濃度依存性に関する特異な現象は，表面吸 着挙動にも反映していることが考えられる。そこで，各 濃度における表面張力の経時変化を調べた。

Fig. -5 に, 平衡表面張力が水の值之同一であった濃 度領域の表面張力経時変化の例として, 界面活性剂濃度 $4.0 \times 10^{-6} \mathrm{M}$ 溶液についての結果を示す。

図を見ると, 表面張力測定用のガラス板が溶液表面に 接触し界面をかく乱した直後は, 純水より低い表面張力 を示すが，時間と共に上昇し純水の值に漸近して, 6 7 $\mathrm{h}$ 後には, 純水の值之同一の值に収束することがわか る。この濃度領域の経時変化は, すべての温度条件下で 類似の傾向を示した。

平衡表面張力が低下し始める濃度と $\mathrm{cmc}$ で囲まれた 中間領域について検討した。

その例として, 濃度 $1.2 \times 10^{-5} \mathrm{M}$ 溶液についての結果

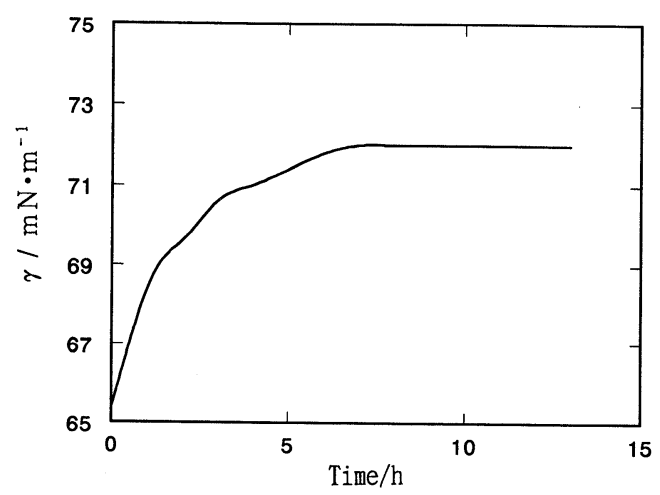

Fig. -5 Time dependence of surface tension for $4.0 \times 10^{-6} \mathrm{M}$ sucrose palmitate solution (the concentration below $\mathrm{cmc}$ ) at $303.1 \mathrm{~K}$. 


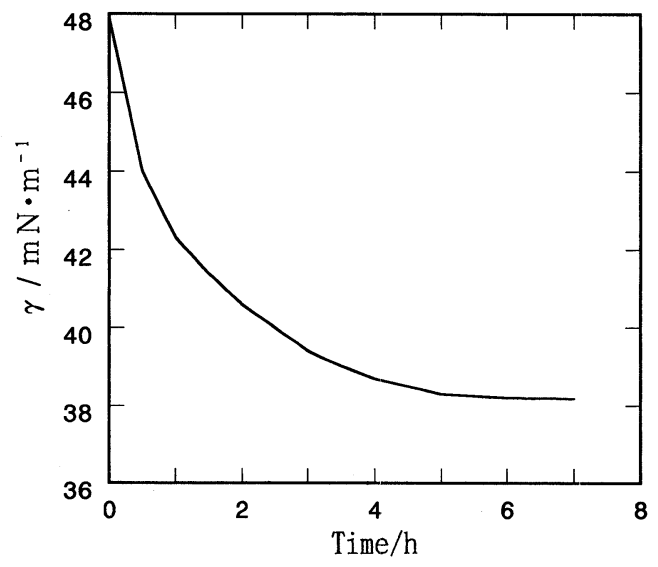

Fig. -6 Time dependence of surface tension for $1.2 \times 10^{-5} \mathrm{M}$ sucrose palmitate solution (the concentration during the reduction of surface tension) at $303.1 \mathrm{~K}$.

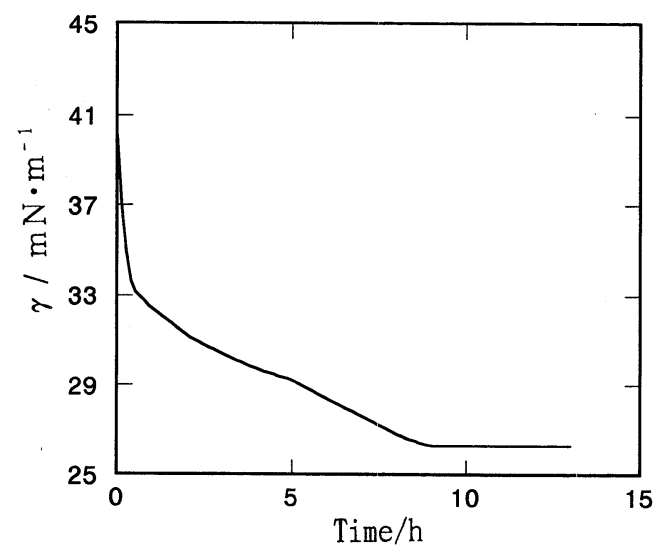

Fig. -7 Time dependence of surface tension for $1.6 \times 10^{-5} \mathrm{M}$ sucrose palmitate solution (the concentration above $\mathrm{cmc}$ ) at $303.1 \mathrm{~K}$.

をFig.-6に示した。この場合は, Fig. -5 の変化とは 対称的に, 界面をかく乱した直後に比較的高い表面張力 を示し, 時間の経過と共に低下し, $5 \sim 6 \mathrm{~h}$ 後に一定值と なった。

次に, $\mathrm{cmc}$ より高い領域の表面張力の経時変化の一 例として, 界面活性剂濃度 $1.6 \times 10^{-5} \mathrm{M}$ 溶液について の結果を Fig.-7 に示す。

Fig. -6 の変化と同様, 界面をかく乱した直後に比較 的高い值を示すが時間と共に低下して一定值となった。 この場合約 $9 \sim 10 \mathrm{~h}$ で, 表面張力が一定值に収束した。

以上, 三つの濃度領域における表面張力の経時変化の 例を示したが，これらの結果は，前述の平衡表面張力の 濃度依存性と良い対応をなしている。従って，このこと からもスクロース脂肪酸エステル濃度が増加しても, 表
面張力が低下しない領域が存在することが示唆される。 また, これらの吸着平衡に要する時間には, 明白な濃 度依存性は見いだせなかった。これは, 表面張力測定開 始時の界面の乱れ状態が異なることを反映したためと思 われる。しかし，いずれの濃度においても表面張力の収 束には, $5 \mathrm{~h}$ 以上の長時間を要した。吸着平衡に達する 時間が長いので, 装置的な安定性や溶液の蒸発の影響を 確認するため, 純水の表面張力の経時変化を測定したと ころ, 純水においては, 表面張力の経時変化が全く認め られなかった。

\section{4 考 察}

Fig. - 2 に示した表面張力の濃度依存の結果と Fig. -5 〜7に示した表面張力の経時変化の結果を考察すると, 平衡表面張力が純水の表面張力と同じ値を示す濃度領域 では，表面張力測定開始時の溶液表面をかく乱すること によりバルク中に存在していた界面活性剂分子の一部が 表面に現れて一時的に比較的低い表面張力を示すが, 時 間経過に伴い，表面に吸着していた界面活性剂分子が， 物理化学的平衡状態になるまでバルク相へ移動すると共 に表面張力が増大し, やがて表面に吸着している界面活 性剂分子が存在しなくなるために純水の表面張力と同一 の值を示すものと解釈できる。

これに対して, $\mathrm{cmc}$ 前後の比較的高い濃度領域で は, 表面張力測定開始時には, 表面かく乱により平衡状 態よりも表面に吸着している分子が少なくなっている が, 時間経過と共に表面への吸着分子の数が増加し, や がて平衡状態に達し，それに対応して表面張力も次第に 低下し，一定值になるものと考えられる。

\section{5 総 括}

スクロース =モノパルミタート水溶液の表面張力の濃 度依存性を検討した結果，ある濃度を越えた時初めて界 面活性を示すような濃度領域が存在するという, 特異な 挙動をすることが明らかとなった。

[平成 6 年 (1994 年) 4 月 18 日受理〕

\section{文 献}

1) 馬場富雄, 武士田剛, 工化, 67, 2077 (1964)

2) I. Wilton, S. Friberg, J. Am. Oil Chem. Soc., 48, 771 (1971)

3) T. M. Herrington, S. S. Sahi, Colloid Surfaces, 17, 103 (1986)

4) W. Wachs, S. Hayano, Kolloid-Z, 181, 139 (1962)

5) D. Abran, F. Boucher, T. Hamanaka, K. Hiraki, Y. Kito, K. Koyama, R. M. Leblanc, H. Machida, G. Munger, M. Seidou, M. Tessier, J. Colloid Interface Sci., 128, 230 (1989) 